\title{
Wintertime hygroscopicity and volatility of ambient urban aerosol particles
}

\author{
Joonas Enroth $^{1}$, Jyri Mikkilä ${ }^{1}$, Zoltán Németh ${ }^{2}$, Markku Kulmala ${ }^{1}$, and Imre Salma ${ }^{2}$ \\ ${ }^{1}$ Department of Physics, P.O. Box 64, 00014, University of Helsinki, Helsinki, Finland \\ ${ }^{2}$ Institute of Chemistry, Eötvös University, P.O. Box 32, 1518 Budapest, Hungary
}

Correspondence: Imre Salma (salma@chem.elte.hu)

Received: 5 October 2017 - Discussion started: 17 November 2017

Revised: 2 March 2018 - Accepted: 14 March 2018 - Published: 4 April 2018

\begin{abstract}
Hygroscopic and volatile properties of atmospheric aerosol particles with dry diameters of (20), 50, 75, 110 and $145 \mathrm{~nm}$ were determined in situ by using a volatilityhygroscopicity tandem differential mobility analyser (VHTDMA) system with a relative humidity of $90 \%$ and denuding temperature of $270{ }^{\circ} \mathrm{C}$ in central Budapest during 2 months in winter 2014-2015. The probability density function of the hygroscopic growth factor (HGF) showed a distinct bimodal distribution. One of the modes was characterised by an overall mean HGF of approximately 1.07 (this corresponds to a hygroscopicity parameter $\kappa$ of 0.033 ) independently of the particle size and was assigned to nearly hydrophobic $(\mathrm{NH})$ particles. Its mean particle number fraction was large, and it decreased monotonically from 69 to $41 \%$ with particle diameter. The other mode showed a mean HGF increasing slightly from 1.31 to 1.38 ( $\kappa$ values from 0.186 to 0.196) with particle diameter, and it was attributed to less hygroscopic ( $\mathrm{LH})$ particles. The mode with more hygroscopic particles was not identified. The probability density function of the volatility GF (VGF) also exhibited a distinct bimodal distribution with an overall mean VGF of approximately 0.96 independently of the particle size, and with another mean VGF increasing from 0.49 to 0.55 with particle diameter. The two modes were associated with less volatile (LV) and volatile (V) particles. The mean particle number fraction for the LV mode decreased from 34 to $21 \%$ with particle diameter. The bimodal distributions indicated that the urban atmospheric aerosol contained an external mixture of particles with a diverse chemical composition. Particles corresponding to the NH and LV modes were assigned mainly to freshly emitted combustion particles, more specifically to vehicle emissions consisting of large
\end{abstract}

mass fractions of soot likely coated with or containing some water-insoluble organic compounds such as non-hygroscopic hydrocarbon-like organics. The hygroscopic particles were ordinarily volatile. They could be composed of moderately transformed aged combustion particles consisting of partly oxygenated organics, inorganic salts and soot. The larger particles contained internally mixed non-volatile chemical species as a refractory residual in $20-25 \%$ of the aerosol material (by volume).

\section{Introduction}

Aerosols influence our life and environment in multiple ways. They affect the climate system and water cycling (Boucher et al., 2013), ecosystems (Mercado et al., 2009), human health and welfare (Lelieveld et al., 2015), the built environment (Brimblecombe, 2016) and visibility (Davidson et al., 2005). One of the key factors in all these processes and their consequences is the size of particles. The size distribution of atmospheric aerosol particles is primarily determined by their formation process. It can be, however, influenced further in the air by condensation or evaporation of vapours (McMurry and Stolzenburg, 1989). Water vapour is the most abundant vapour in the troposphere; it is a minor constituent of the air, while the other vapours or their precursors are present in trace concentrations. Water uptake by aerosol particles or water evaporation from particles under subsaturated conditions (and thus its hygroscopicity) is explained by Köhler theory. The interactions between water vapour and particles are affected by the size, chemical composition, surface tension and water activity of particles on one side and the 
meteorological conditions, specifically air temperature $(T)$ and relative humidity $(\mathrm{RH})$, on the other side. These relationships have a special climate and environmental relevance for droplet formation on cloud condensation nuclei (CCN). Some particles from specific emission or formation sources contain relatively large amounts of semi-volatile chemical compounds (other than water), which can evaporate from the particles depending on ambient conditions, mainly on air $T$ according to their partitioning between the condensed and gas phases. It is worth noting that dissolution of some atmospheric gases into droplets and their subsequent water-phase chemical reactions can also change the particle size (Meng and Seinfeld, 1994; Kerminen and Wexler, 1995). The dissolution takes place preferentially with accumulation-mode particles because of the largest total surface area of this mode (and it causes the splitting the accumulation mode into the condensation and droplet submodes). Nevertheless, the related absolute increase in the diameter is small due to the fact that the relevant gases are ordinarily present in trace concentrations, and the relative diameter increments are modest considering the diameter range of these particles. Influence of the dissolution-chemical reaction process on the particle size is smaller than that of condensation of water vapour or evaporation of semi-volatile chemical species including water, and therefore it can usually be disregarded. The hygroscopic and volatile properties have been increasingly recognised and used for global modelling purposes (McFiggans et al., 2006; Pringle et al., 2010; Rissler et al., 2010). At the same time, determination of the changes in particle size for different dry diameters under various RHs and $T \mathrm{~s}$ can also supply valuable indirect in situ information on chemical composition, extent of external or internal mixing, surface coatings and chemical reactivity of particles (Massoli et al., 2010; Wu et al., 2016; Cai et al., 2017). The hygroscopic properties under subsaturated conditions and volatility of ambient particles can be studied by online tandem differential mobility analyser (TDMA) systems, including the volatility-hygroscopicity TDMA (VH-TDMA). The method has particular importance since it is rather difficult to obtain direct information on the chemical composition of ambient ultrafine (UF) particles (with $d<100 \mathrm{~nm}$ ) due to the small total mass represented by them and their dynamic processes. The measurements can also be used for determining the timescales for atmospheric chemical or physicochemical transformations of freshly emitted less hygroscopic particles into more hygroscopic types, which is a relevant issue particularly in cities. The technique has been successfully applied in remote, marine, rural or semi-urban atmospheric environments worldwide, and the results and conclusions were summarised in a review paper by Swietlicki et al. (2008). Measurements on complex ambient mixtures explicitly in urban centres have also been increasing (Cocker et al., 2001; Baltensperger et al., 2002; Ferron et al., 2005; Massling et al., 2005; Kuwata and Kondo, 2008; Tiitta et al., 2010; Jurányi et al., 2013; Kamilli et al., 2014; Wu et al., 2016; Cheung et al., 2016; Cai et al., 2017). It turned out from the studies that the hygroscopic and volatile properties vary strongly with the location and the origin of air masses, and in addition the urban-type air pollution can strongly influence these properties. Moreover, multicomponent chemical mixtures of inorganic salts and organic compounds including coatings, which are typically present in ambient aerosol particles in cities, are poorly characterised and understood. The potential effects concern many people since there is a spatial coincidence between the air pollution and population density in cities.

As part of a long-term cooperation between Eötvös University, Budapest, and the University of Helsinki in the field of atmospheric aerosol research (e.g. Salma et al., 2016b), in situ VH-TDMA measurements were performed in central Budapest for the first time together with other supporting measurements for 2 months in winter. The major objectives of the present paper are to present the results on hygroscopic and volatile properties of aerosol particles with various dry diameters, to improve the geographical coverage with this type of the measurements with regard to the Carpathian Basin, to interpret the two data sets jointly, to identify and discuss the mixing state and source processes of particles, and to conclude their implications for urban aerosol. The results and conclusion are to contribute to the improved understanding of hygroscopic and volatile properties of the urban-type atmospheric environment in general.

\section{Experimental methods}

The measurements took place at the Budapest Platform for Aerosol Research and Training (BpART) research facility (Salma et al., 2016a) in Budapest from 9 December 2014 to 9 February 2015. The location represents a well-mixed, average atmospheric environment for the city centre. The sampling inlets were set up at heights between 12 and $13 \mathrm{~m}$ above the street level of the closest road and were located at a distance of $85 \mathrm{~m}$ from the Danube River. Distance of $\mathrm{Bu}-$ dapest to the Adriatic Sea, Baltic Sea, Black Sea and North Sea are approximately 450,780, 830 and $1200 \mathrm{~km}$, respectively. The mean and standard deviation (SD) of air $T$ and RH inside the BpART during the measurement campaign were $20 \pm 1{ }^{\circ} \mathrm{C}$ and $28 \pm 8 \%$, respectively, and the air $T$ stratification was avoided by extra fans located properly inside the facility. The wintertime median concentrations of elemental carbon (EC), organic carbon (OC) and particulate matter (PM) mass in the $\mathrm{PM}_{2.5}$ size fraction were 0.97, 4.9 and $25 \mathrm{\mu g} \mathrm{m}^{-3}$, respectively (Salma et al., 2017). The mean contributions of EC and organic matter (OM, with an OM/OC mass conversion factor of 1.6) to the $\mathrm{PM}_{2.5}$ mass and SDs were $4.8 \pm 2.1$ and $37 \pm 10 \%$, respectively, while the contribution of $\left(\mathrm{NH}_{4}\right)_{2} \mathrm{SO}_{4}$ and $\mathrm{NH}_{4} \mathrm{NO}_{3}$ derived in an earlier study in spring were 24 and $3 \%$, respectively. The online instruments deployed in the present campaign were a VH- 
TDMA system, a differential mobility particle sizer (DMPS) system and various meteorological sensors, which were operated in parallel.

The key instrument related to this study was a VH-TDMA system described by Hakala et al. (2017). In short, the sample air with a flow rate of $2 \mathrm{~L} \mathrm{~min}^{-1}$ was dried to $\mathrm{RH}<10 \%$ using a silica-gel diffusion dryer at indoor temperatures; then the equilibrium electric charge distribution of the aerosol particles was ensured by using a ${ }^{14} \mathrm{C}$ radioactive bipolar charger. Particles with median dry diameters of 20, 50, 75, 110 and $145 \mathrm{~nm}$ were preselected in a narrow quasi-monodisperse size range by a $10.9 \mathrm{~cm}$ long Vienna-type differential mobility analyser (DMA1). The dry diameters were selected considering the shape of the particle number size distribution in Budapest to cover the Aitken and accumulation modes. The inlet air flow was then separated into two flows with equal rates, which continued either to a humidifying chamber with an enhanced RH to allow water uptake or to a thermal denuder with a higher $T$ to allow evaporation. The humidifier was a Gore-Tex tube with a length of $2.5 \mathrm{~cm}$ in a heated MilliQ water bath. The RH in the humidifier was set to $85 \%$ in the very beginning of the campaign, and it was increased to $90 \%$, which is commonly regarded as the standard humidification. The mean RH and its SD were $90.0 \pm 0.4 \%$ during the second (much longer) part of the campaign. The RH was maintained by a PID controller with a relatively slow response, which ensures that the RH during each scan remains stable. The mean difference in the RH values between the scans stayed $<0.16 \%$. The thermal denuder was a wellinsulated cylindrical metal tube maintained at a mean temperature and SD of $270.0 \pm 0.1^{\circ} \mathrm{C}$ by electrical resistance wires and heat insulations. This temperature was selected as a compromise by considering the thermal behaviour of relevant and abundant inorganic salts, several types of organic compounds and soot (Park et al., 2009; Hakala et al., 2017) and the conclusions of varying temperature protocols in previous studies with real ambient aerosol particles (Tritscher et al., 2011; Hong et al., 2014; Cai et al., 2017). Atmospheric sulfates, nitrates and most organics are usually volatile at this temperature, while soot and some organic polymers remain refractory. The two main classes can be advantageously combined with the hygroscopicity measurements. The centreline residence times of particles in the humidifying section and thermal denuder were 0.6 and $0.5 \mathrm{~s}$, respectively, which is adequate for equilibrium particle growth/evaporation of typical inorganic salts (Chan and Chan, 2005). The humidifier and denuder were operated in parallel, giving simultaneous data on hygroscopic and volatile properties of particles. The advantage of this combination is a relatively good time resolution, which is an important factor for rapidly varying urban atmospheric environments. The changes in particle diameter after the humidifier were determined by a Vienna-type DMA (DMA2a) with a length of $28 \mathrm{~cm}$ and a condensation particle counter (CPC, TSI, model 3772 , operated with an option of water removal on). The sheath air flow of the DMA2a was also humidified to the selected RH. The changes in particle diameter after the thermal denuder were measured by a Vienna-type DMA (DMA2b) with a length of $10.9 \mathrm{~cm}$ and a CPC (TSI, model 3010). The concentration of the sizeselected particles in the denuded air flow was low enough to prevent recondensation after the denuder (Park et al., 2009). The $T$ and RH of the air flows were monitored just at the second set of DMAs. The RH was measured by using a chilled-mirror dew point hygrometer located in the excess air flow of the DMA2a. The DMA1, DMA2a and DMA2b were all operated with a closed-loop sheath air flow system with flow rates of 20,10 and $9 \mathrm{~L} \mathrm{~min}^{-1}$, respectively. The time resolution of the VH-TDMA system was $18 \mathrm{~min}$, which has high importance in dynamically changing urban atmospheres. Calibration, a quality check of the hygroscopic diameter growth factor (HGF) and an operation check of the volatility diameter growth factor (VGF) for all selected diameters were performed by nebulising dilute solution of analytical-grade $\left(\mathrm{NH}_{4}\right)_{2} \mathrm{SO}_{4}$ into the filtered inlet air flow of the VH-TDMA system. The system was operated according to international recommendations (Duplissy et al., 2009; Massling et al., 2011; Cheung et al., 2016; Cai et al., 2017).

The DMPS used was a flow-switching-type system (Salma et al., 2011b, 2016a). Its main components are a radioactive $\left({ }^{60} \mathrm{Ni}\right)$ bipolar charger, a Nafion semi-permeable membrane dryer, a $28 \mathrm{~cm}$ long Vienna-type DMA and a butanolbased CPC (TSI, model 3775). It measures particle number size distributions in an electrical mobility diameter range from 6 to $1000 \mathrm{~nm}$ in the dry state of particles (with a $\mathrm{RH}<30 \%$ ) in 30 channels with a time resolution of approximately $8 \mathrm{~min}$. The sample flow rate is $2.0 \mathrm{~L} \mathrm{~min}^{-1}$ in high-flow mode and $0.30 \mathrm{~L} \mathrm{~min}^{-1}$ in low-flow mode with sheath air flow rates 10 times larger than for the sample flows. The DMPS measurements were performed according to the recommendations of the international technical standard (Wiedensohler et al., 2012). Weather shield and insect net were adopted to both aerosol inlets. The meteorological data were available from the Urban Climatological Station of the Hungarian Meteorological Service operated at a height of $10 \mathrm{~m}$ above the roof level of the building (at a height of $39 \mathrm{~m}$ above the ground) at a distance of about $40 \mathrm{~m}$ from the BpART facility and from a simpler on-site meteorological station. Standardised meteorological measurements of $T, \mathrm{RH}$, wind speed (WS) and wind direction (WD) were recorded with a time resolution of $10 \mathrm{~min}$.

\section{Data evaluation}

The ratio of the particle diameter after the treatment in the humidifier or thermal denuder to the initially selected diameter is the HGF or VGF, respectively. It expresses both possible growth and shrinkage of particles. For ambient particles, the HGFs and VGFs are spread in a distribution, which was measured by holding the particle size selected by the DMA1 
constant and scanning by the second set of DMAs (DMA2a and $2 \mathrm{~b}$ ) through possible diameter ranges that correspond to HGFs from 0.9 to 2.0 and to VGFs from 1.3 to 0.3 . This resulted in a distribution of the HGF or VGF, which is referred to as the growth factor probability density function (PDF). It is, however, a smoothed and skewed form, which needs to be mathematically inverted to derive the distribution accurately since the transfer function of the second set of DMAs has a finite width, and since their total transfer probabilities depend on the classifying voltage and operational parameters of the DMA (Swietlicki et al., 2008; Gysel et al., 2009). The inversion process yields the true growth factor PDF for each scan, and it is also normalised to unity. The inversion was accomplished by applying the program package TDMAinv (Gysel et al., 2009) in IGOR Pro software. The program package was shown to be robust, appropriate and adequate in several previous studies (e.g. Liu et al., 2011; Hong et al., 2014). The hygroscopic property was also expressed by a hygroscopicity parameter ( $\kappa$ value; Petters and Kreidenweis, 2007). The $\kappa$ value is a compound parameter with more sophisticated interpretation than the hygroscopic GF, but it can be used in the Köhler model as a proxy for the chemical composition without explicitly knowing the density, molecular mass, van't Hoff factor and osmotic coefficient or dissociation number of each chemical component. It was calculated for each HGF as

$\kappa=\left(\mathrm{HGF}^{3}-1\right)\left[\frac{1}{S} \exp \left(\frac{4 \sigma M_{\mathrm{w}}}{R T \rho_{\mathrm{w}} D_{\mathrm{d}} \mathrm{HGF}}\right)-1\right]$,

where $S$ is the saturation ratio of water $(S=\mathrm{RH}$, where $\mathrm{RH}$ is expressed as a fraction), $\sigma$ is the surface tension of the droplet-air interface at the composition of the droplet (see below), $M_{\mathrm{w}}$ is the molecular mass of water $\left(0.018015 \mathrm{~kg} \mathrm{~mol}^{-1}\right), R$ is the universal gas constant $\left(8.3145 \mathrm{~J} \mathrm{~mol}^{-1} \mathrm{~K}^{-1}\right), T$ is the droplet temperature (obtained directly from the DMA as $298.15 \mathrm{~K}), \rho_{\mathrm{w}}$ is the density of water in the droplet $\left(997.05 \mathrm{~kg} \mathrm{~m}^{-3}\right.$ at $\left.298.15 \mathrm{~K}\right)$ and $D_{\mathrm{d}}$ is the dry diameter of the particle. The $\sigma$ was assumed to be that of pure water $\left(\sigma=72.0 \mathrm{mN} \mathrm{m}^{-1}\right.$ at $\left.298.15 \mathrm{~K}\right)$. It was shown that some organic chemical species in atmospheric aerosol particles such as humic-like substances (HULIS) are surface active and can lower the surface tension of the water droplet (Facchini et al., 1999; Salma et al., 2006). The use of a smaller $\sigma$ than for pure water yields smaller $\kappa$ values. The depression of $\sigma$ in time is mainly controlled by diffusion of HULIS from the bulk of the droplet to its surface, and it takes several hours to reach the thermodynamic equilibrium at medium concentrations (Salma et al., 2006). This also means that the extent of the actual decrease is kinetically limited to larger-than-equilibrium values, and therefore the utilisation of $\sigma=60 \mathrm{mN} \mathrm{m}^{-1}$ is expected to represent a lower estimate. The $\kappa$ values obtained by this surface tension changed by a mean factor of $0.97-0.98$ for particles with a diameter of 70, 110 and $145 \mathrm{~nm}$, while the mean factor for particles with a diameter of $50 \mathrm{~nm}$ became 0.95 . This all implies that the possible alterations related to the lower surface tension than that of water are small with respect to estimated experimental uncertainties in the determination of the HGFs (up to 15-20\%), and that the calculations with $\sigma$ for water seem to be a sensible approach to reality in the size range and RH considered in the present study. This is also confirmed in an earlier article, according to which the sensitivity of hygroscopic growth to surface tension becomes more important with decreasing dry particle diameter and increasing RH since these are the conditions under which HGFs or $\kappa$ values are most sensitive to the Kelvin factor (Swietlicki et al., 2008). Therefore, the surface tension of pure water was adopted in the calculations. The soluble particle volume fraction is often used to classify different groups of hygroscopic growth in order to facilitate data comparability. Here, we utilise $\kappa$ values and HGFs to define commonly observed hygroscopic groups (Liu et al., 2011). The limits of the groups are, however, not exactly determined. They are often set as (1) $\kappa \leq 0.10$ (HGF $\leq 1.21)$ : nearly hydrophobic (NH) particles; $(2) \kappa \approx 0.10-0.20(\mathrm{HGF}=1.21-1.37)$ : less hygroscopic (LH) particles; and (3) $\kappa>0.20$ (HGF $>1.37$ ): more hygroscopic $(\mathrm{MH})$ particles. The HGFs above refer to particles with a diameter of $100 \mathrm{~nm}$ and $\mathrm{RH}=90 \%$, and vary with $D_{\mathrm{d}}$ and RH. On the one side, small values of $\kappa$ indicate low $\mathrm{CCN}$-active behaviour. As $\kappa$ approaches 0 , the particle resemble an insoluble but wettable particle. On the other side, the upper limit for the most hygroscopic species typically found in the marine atmospheric aerosol particles (e.g. $\mathrm{NaCl})$ is $\kappa \approx 1.4(\mathrm{HGF} \approx 1.85)$ at $\mathrm{RH}=90 \%$ (Petters and Kreidenweis, 2007).

The volume fraction remaining (VFR) after the thermal treatment was calculated from the VGF assuming spherical shape of particles both before and after the treatment (Häkkinen et al., 2012). The mean growth factor was calculated using the retrieved GF-PDF as

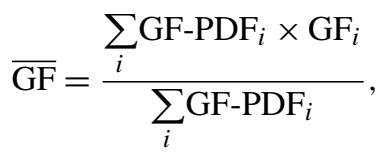

where GF-PDF $i$ is the value of the PDF at $\mathrm{GF}_{i}$. Number fraction (NF) of particles in the different modes was computed as

$\mathrm{NF}=\frac{\sum_{i}^{j} \text { GF-PD } F_{i}}{\sum_{i} \mathrm{GF}-\mathrm{PDF}_{i}}$.

The partial sum in the numerator of Eq. (3) was calculated either (1) for the HGF interval from $i=0.9$ to $j=1.2$ for the NH mode, and from $i=1.2$ to $j=2.3$ for the LH mode (see Fig. 2a), or (2) for the VGF interval from $i=0.3$ to $j=0.8$ for the volatile mode, and from $i=0.8$ to $j=1.3$ for the LV mode (see Fig. 2b). Complete evaporation of particles in the thermal denuder and the possible size-dependent particle loss within the instrument were not taken into account in the 


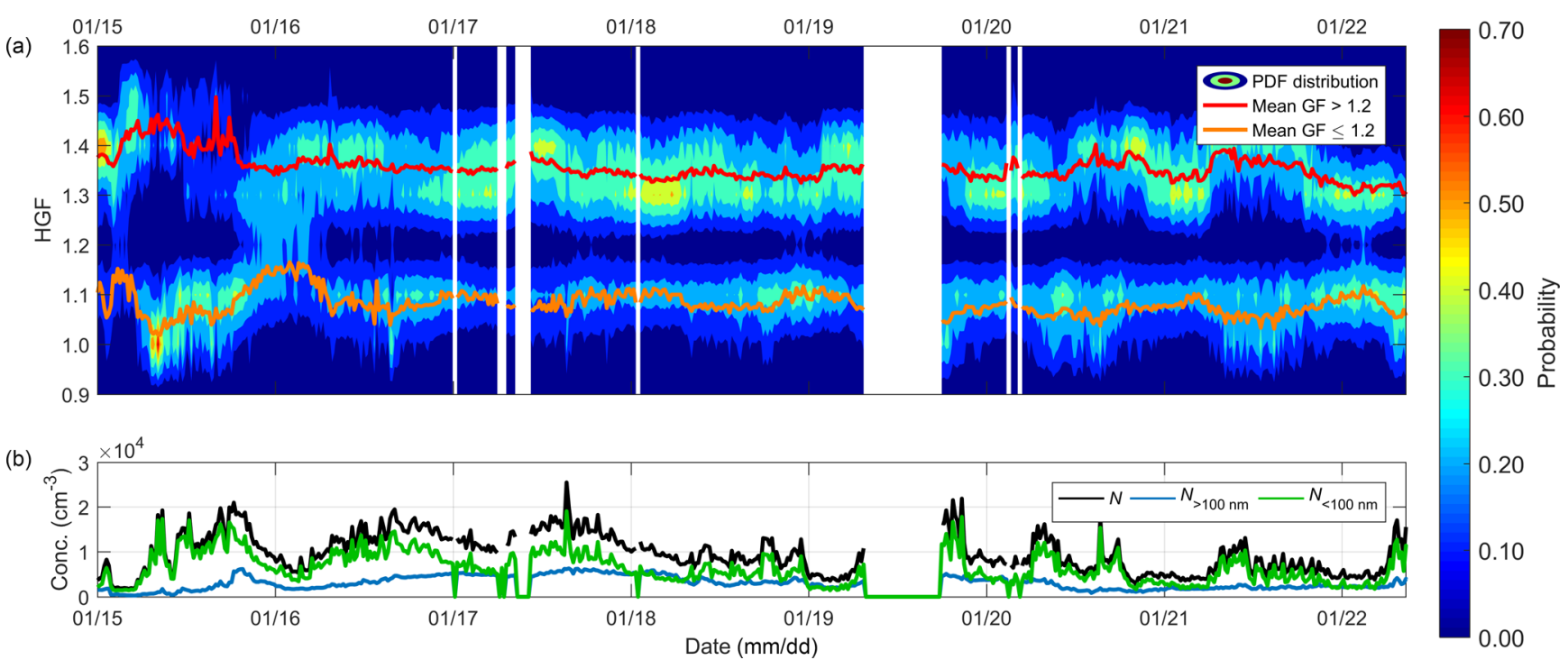

Figure 1. Temporal variability of the hygroscopic diameter growth factor probability density function (HGF-PDF) (a) at a RH=90\% for particles with a dry diameter of $145 \mathrm{~nm}$ from 15 to 22 January 2015. The orange line displays the mean HGF of the nearly hydrophobic mode $\left(\mathrm{HGF}_{\mathrm{NH}}\right)$, while the red line shows the mean $\mathrm{HGF}$ of the less hygroscopic mode $\left(\mathrm{HGF}_{\mathrm{LH}}\right)$. Total particle number concentration $(N$, black line) and concentrations of $N_{<100}$ (green line) and $N_{>100}$ (blue line) are also shown in (b).

present study. The fraction of completely evaporated particles was, however, roughly estimated to be between 60 and $32 \%$ for particle diameters of 50 and $145 \mathrm{~nm}$, respectively. Evaluation of the measured DMPS data was performed according to the procedure protocol recommended by Kulmala et al. (2012). Mathematically inverted DMPS data were utilised for calculating particle number concentrations in the particle diameter ranges from 6 to $100 \mathrm{~nm}$ (UF particle number concentration, $\left.N_{<100}\right)$, from 100 to $1000 \mathrm{~nm}\left(N_{>100}\right)$ and from 6 to $1000 \mathrm{~nm}$ (total particle number concentration, $N$ ). Median particle number size distribution was derived from the individual concentration data. Diurnal variation for a selected variable was obtained by averaging the measured data for the corresponding hour, and then by averaging the hourly means for the whole time interval.

\section{Results and discussion}

Most of the measurement period consisted of mild and moist winter weather. The air $T$ and $\mathrm{RH}$ ranged from -9 to $17^{\circ} \mathrm{C}$ and from 40 to $99 \%$, respectively, with means and SDs of $3.0 \pm 4.2{ }^{\circ} \mathrm{C}$ and $84 \pm 13 \%$, respectively. No extreme wind conditions were encountered; the mean WS and its SD were $1.9 \pm 1.7 \mathrm{~m} \mathrm{~s}^{-1}$. The median $N$ and UF particle number concentration were $5.0 \times 10^{3} \mathrm{~cm}^{-3}$ and $4.1 \times 10^{3} \mathrm{~cm}^{-3}$, respectively, for the measurement campaign, and the mean UF/ $N$ concentration ratio and its SD were $82 \pm 9 \%$. The median concentrations are below the annual medians (Salma et al., 2016b). There were four quantifiable new aerosol particle formation and growth events identified in the DMPS data set during the VH-TDMA measurement campaign. Unfortunately, only one of them was fully covered by the $\mathrm{VH}$ TDMA system, and therefore no representative conclusion can be drawn for them (cf. Kerminen et al., 2012; Wu et al., 2016).

\subsection{Growth factor spectra and their temporal variability}

Time series of the HGF-PDF for particles with a dry diameter of $145 \mathrm{~nm}$ at $\mathrm{RH}=90 \%$ and particle number concentrations in various size fractions for approximately 1 week are shown in Fig. 1 as an example. The white bands indicate missing data. The HGF-PDF exhibited bimodal distribution. The mode with the smaller HGF values represented NH particles, while the other mode with the larger HGFs was related to LH particles. The two modes were constantly present and were well separated during the whole campaign despite the large variations in $N$ and $N_{>100}$ concentrations. Figure 1 also confirms that the classification of the $\mathrm{NH}$ and $\mathrm{LH}$ groups (see Sect. 3) was appropriate in Budapest. The contribution of the two modes was size dependent (which is quantified in Table 1 and is discussed below). Importance of the $\mathrm{NH}$ mode decreased with particle size. The smallest $(20 \mathrm{~nm})$ particles already resembled a unimodal distribution with only $\mathrm{NH}$ mode for most of the time. Two distinct modes showed up in the VGF-PDF spectrum as well, and they were also constantly present during the whole campaign. The mode with the VGF $>0.8$ was assigned to less volatile (LV) particles, while the mode exhibiting VGF $\leq 0.8$ was associated with volatile $(\mathrm{V})$ particles. These two well-separated groups 
Table 1. Mean hygroscopic growth factor (HGF) and mean hygroscopicity parameter $(\kappa)$ separately for nearly hydrophobic (NH) mode $(\mathrm{HGF}<1.2)$ and less hygroscopic $(\mathrm{LH})$ mode $(1.45>\mathrm{HGF} \geq 1.2)$ obtained for different dry particle diameters $\left(D_{\mathrm{d}}\right)$ at a mean $\mathrm{RH}$ of $90 \%$, and mean volatility growth factors (VGFs) separately for less volatile (LV) mode and for volatile (V) mode for different $D_{\mathrm{d}}$ values at a mean denuding temperature of $270^{\circ} \mathrm{C}$. Mean number fraction (NF, in \%) with respect to the total particle number concentration and SD for each mode are also given.

\begin{tabular}{|c|c|c|c|c|c|c|c|c|}
\hline \multirow{2}{*}{$\begin{array}{l}D_{\mathrm{d}} \\
\text { property }\end{array}$} & \multicolumn{2}{|c|}{$50 \mathrm{~nm}$} & \multicolumn{2}{|c|}{$75 \mathrm{~nm}$} & \multicolumn{2}{|c|}{$110 \mathrm{~nm}$} & \multicolumn{2}{|c|}{$145 \mathrm{~nm}$} \\
\hline & Mean & SD & Mean & SD & Mean & SD & Mean & SD \\
\hline $\mathrm{HGF}_{\mathrm{NH}}$ & 1.07 & 0.04 & 1.07 & 0.04 & 1.09 & 0.03 & 1.09 & 0.03 \\
\hline$\kappa_{\mathrm{NH}}$ & 0.034 & 0.020 & 0.033 & 0.018 & 0.037 & 0.015 & 0.037 & 0.012 \\
\hline $\mathrm{NF}_{\mathrm{NH}}$ & 69 & 17 & 53 & 16 & 47 & 13 & 41 & 11 \\
\hline $\mathrm{HGF}_{\mathrm{LH}}$ & 1.31 & 0.02 & 1.35 & 0.03 & 1.37 & 0.03 & 1.38 & 0.04 \\
\hline$\kappa_{\mathrm{LH}}$ & 0.190 & 0.015 & 0.197 & 0.019 & 0.20 & 0.02 & 0.20 & 0.03 \\
\hline $\mathrm{NF}_{\mathrm{LH}}$ & 31 & 17 & 47 & 16 & 53 & 13 & 59 & 11 \\
\hline $\mathrm{VGF}_{\mathrm{LV}}$ & 0.96 & 0.02 & 0.96 & 0.02 & 0.97 & 0.02 & 0.96 & 0.02 \\
\hline $\mathrm{NF}_{\mathrm{LV}}$ & 34 & 17 & 30 & 16 & 24 & 14 & 21 & 12 \\
\hline $\mathrm{VGF}_{\mathrm{V}}$ & 0.49 & 0.05 & 0.52 & 0.04 & 0.54 & 0.04 & 0.54 & 0.04 \\
\hline $\mathrm{NF}_{\mathrm{V}}$ & 66 & 17 & 70 & 16 & 76 & 14 & 79 & 12 \\
\hline
\end{tabular}

of particles (two modes) based on volatile properties appear satisfactory under actual experimental and atmospheric conditions and for our present purposes. Other, more detailed classifications are also possible (Cheung et al., 2016). The bimodal distributions indicated that the particles had separate chemical composition, and thus they were present in an external mixture, except for $20 \mathrm{~nm}$ particles, which basically showed an internal mixture of constituents. The relative contribution of the modes was highly variable, which can be explained by the temporal variability in the intensity of the major emission and formation sources of the corresponding particles, in their atmospheric transformation processes, and by the influence of different air masses.

\subsection{Averages of hygroscopic and volatile properties}

Median particle number size distribution together with the mean HGF-PDF and mean VGF-PDF for different particle diameters are shown in Fig. 2. The size distribution (Fig. 2a) demonstrates that particles in cities mainly originate from multiple complex local and regional emission and formation sources. Its broadening was caused by the averaging of the individual data as well. Figure $2 \mathrm{a}$ also shows that the selected diameters of 20,50,75, 110 and $145 \mathrm{~nm}$ represent a plateau of the size distribution, and that the median ambient concentrations of these particles were similar to each other (approximately $1.2 \times 10^{3} \mathrm{~cm}^{-3}$ ). The particles with a diameter of $20 \mathrm{~nm}$ were omitted from the volatility evaluation and Fig. 2c because they appeared at the lower end of the VGF range after the shrinkage; thus their diameters were close to the detection limit of the CPC (TSI model 3010) used as the detector, and they were also subjected to enhanced diffusion losses. The mean curves for HGFs and VGFs exhibited clear bimodal character. The relative contribution of $\mathrm{NH}$ mode in the HGF-PDF (Fig. 2b) decreased with particle di- ameter, while there was no similar obvious tendency for the VGF-PDF (Fig. 2c).

The mean HGFs and $\kappa$ values separately for the $\mathrm{NH}$ and LH modes, and the mean VGFs separately for the LV and $\mathrm{V}$ modes together with the number fractions of particles in each mode for the different dry diameters, are summarised in Table 1. Relatively small size dependency was observed for the growth of the $\mathrm{NH}$ and $\mathrm{LH}$ modes as well as for the shrinkage of the LV and V modes, while the number fraction of particles in the modes varied substantially. Specifically, the mean $\mathrm{HGF}_{\mathrm{NH}}$ mode of approximately 1.08 did not seem to depend on particle size, while the mean $\mathrm{NF}_{\mathrm{NH}}$ decreased monotonically and substantially, from 69 to $41 \%$ with particle diameter. It is mentioned that approximately $85 \%$ of particles with a diameter of $20 \mathrm{~nm}$ were associated with the NH mode, and they showed the largest time variation. The variation in the $\mathrm{HGF}_{\mathrm{NH}}$ mentioned above was small. The differences in the growth behaviour are expected to become larger with RH under subsaturated conditions, so a more reliable interpretation of this change (variability or tendency) would likely be achieved by dedicated experiments with RHs of $95 \%$ or higher. The situation was similar for the LV particles; thus the mean $\mathrm{VGF}_{\mathrm{LV}}$ stayed constant on a level of approximately 0.96 independently of the particle size, while the particle number fraction in the LV mode $\left(\mathrm{NF}_{\mathrm{LV}}\right)$ decreased from 34 to $21 \%$, although its extent was less pronounced than for the $\mathrm{NF}_{\mathrm{NH}}$ particles. The $\mathrm{NH}$ mode and the LV mode were jointly related to freshly emitted combustion particles (see Sect. 4.3) consisting of large volume/mass fractions of refractory matter (see Sect. 4.5), most likely soot and some water-insoluble organic compounds (Liu et al., 2013; Cheung et al., 2016). The latter species can be a mixture of non-hygroscopic hydrocarbonlike organic aerosol in the condensed phase and adsorbed volatile organic compounds (VOCs) from the gas phase in 

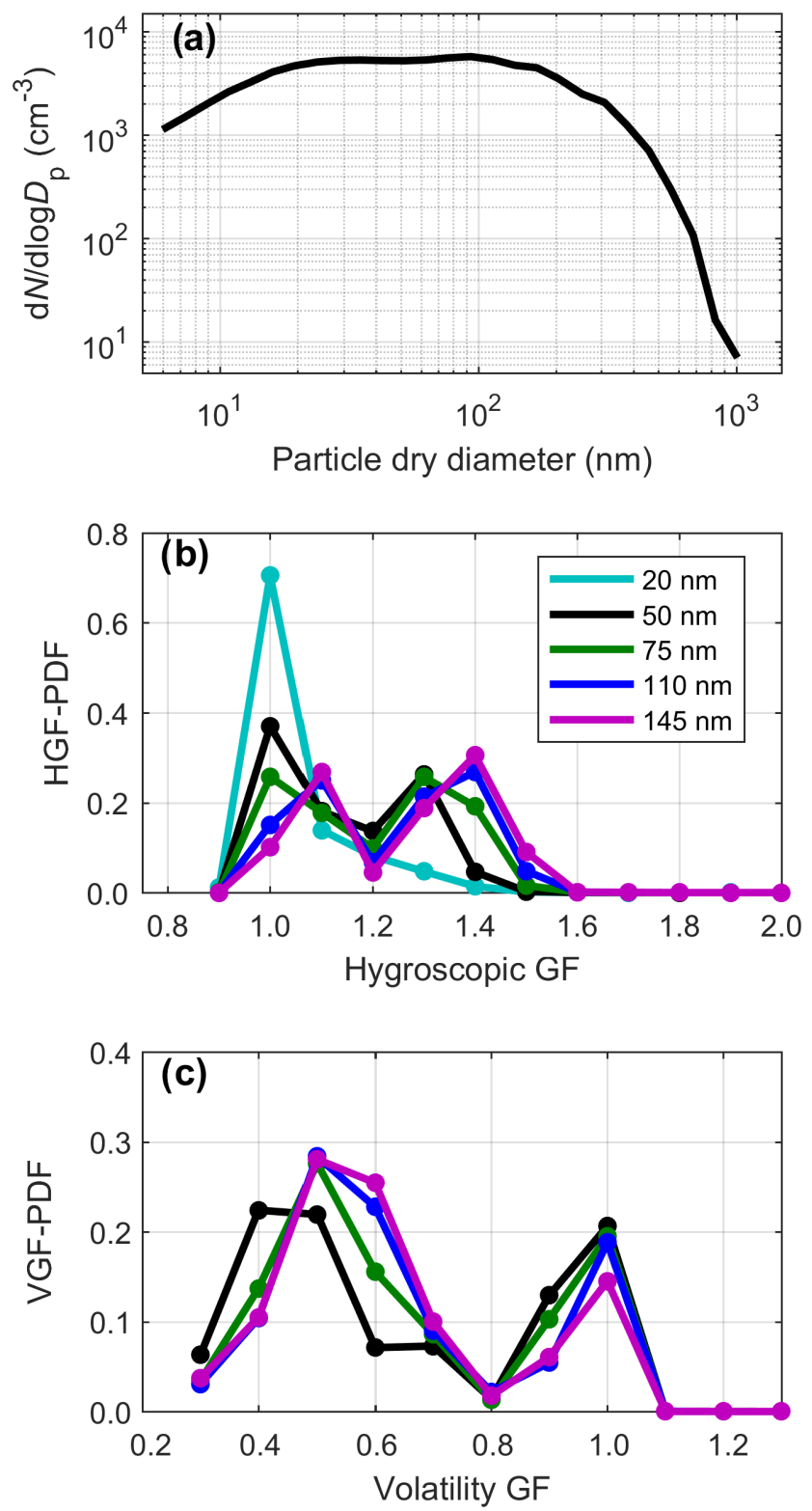

Figure 2. Median particle number size distribution for the whole campaign (a) together with the mean hygroscopic diameter growth factor probability density function (HGF-PDF; b) and volatility diameter growth factor probability density function (VGF-PDF; c) for different dry particle diameters. (b) and (c) have shared legends.

relatively large amounts. The tendencies in the hygroscopic and volatile properties and in the particle number fraction for the two modes mentioned are ordinarily observed in urban VH-TDMA studies (e.g., Ferron et al., 2005) since the particle number size distribution of soot from traffic emissions peaks between 50 and $100 \mathrm{~nm}$ (Weingartner et al., 1997). It was previously concluded that uncoated fresh soot particles (although of somewhat larger diameters than $145 \mathrm{~nm}$ ) showed neither hygroscopic growth nor water activation, while their coating with succinic acid, sulfuric acid or polycyclic aromatic hydrocarbons (PAHs) influenced the hygroscopic growth in a complex way (Henning et al., 2012). Polyaromatic hydrocarbons are usually not hygroscopic; they are slightly soluble or even insoluble in water, and their solubility decreases with molecular mass. It was found that sulfuric acid reacted with PAHs and likely formed products with lower molecular mass than the initial PAHs. These products had higher solubility in water, and as a consequence the hygroscopic growth and activated fraction increased due to (1) the products of this reaction and (2) the unconsumed coating fraction itself. The diameter change depended on the amount and type of the coatings, on the "humidity history" of particles (coating by solution layer or solid film) and on the carrier gas used in the experiments. The interaction between the soot particles and water vapour also included hygroscopic shrinkage. Hygroscopic GFs up to 1.11 were obtained with succinic acid at $\mathrm{RH}=98 \%$ for particles with 375 and $500 \mathrm{~nm}$ dry diameter (Henning et al., 2012). It has to be noted that succinic acid coating on soot particles appears to be a good example of oxygenated organic substances in atmospheric environments strongly influenced by biogenic activities, while the situation with the coatings in urban environments could be different. Atmospheric fresh soot agglomerates have fractal structure, which can be reconstructed when exposed to high RH due to capillary condensation or due to filling up cavities, leading to compaction (Weingartner et al., 1995). The particles after the structural change (i.e. collapse) become less fractal-like or more compact, which results in decreased electrical mobility diameter and thus leads to particle shrinkage $(\mathrm{HGF}<1)$ and, finally, to underestimated overall HGF if it is obtained by diameterbased methods. The restructuring has been observed for different soot types (Weingartner et al., 1995; Tritscher et al., 2011) and for particles with a $D_{\mathrm{d}}>100 \mathrm{~nm}$ (Martin et al., 2012). The $\mathrm{HGF}_{\mathrm{LH}}$ increased monotonically but in a modest way (from 1.31 to 1.38 ) with particle size, while the $\mathrm{NF}_{\mathrm{LH}}$ increased with diameter from $29 \%$ (for $D_{\mathrm{d}}=20 \mathrm{~nm}$ ) to $59 \%$. It is worth realising that the HGFs for pure $\left(\mathrm{NH}_{4}\right)_{2} \mathrm{SO}_{4}$ and $\mathrm{NH}_{4} \mathrm{NO}_{3}$ (Park et al., 2009) are substantially larger than the measured values. These particles can be composed of moderately transformed aged soot-containing combustion particles comprising also partly oxygenated organics and inorganic salts (Duplissy et al., 2011; Liu et al., 2013). This view is further confirmed by a high-resolution transmission electron microscopy with electron energy-loss spectroscopy (TEM/EELS) study of individual particles at the BpART facility (Németh et al., 2015). Both regional background sources and urban (local) emissions can contribute to these particles (Swietlicki et al., 2008), which results in complex mixtures. The whole explanation is also coherent (Liu et al., 2013) with the fact that the mixing state of soot particles is mostly determined in a relatively close distance from their emission sources. Mean number fraction of volatile particles $\left(\mathrm{NF}_{\mathrm{V}}\right)$ increased from 66 to $79 \%$ with particle diame- 
ter, and it was accompanied by almost identical mean VGFs (0.49-0.54 with a relative SD of approximately $9 \%)$. All these findings correspond to earlier similar observations in urban environments or metropolitan regions and support the idea that particles with larger volatility consist of soot particles internally mixed (coated) with volatile material (Cheng et al., 2006; Wehner et al., 2009; Cheung et al., 2016).

The HGFs observed in Budapest are also in line with the results reported for other urban areas (Cocker et al., 2001; Baltensperger et al., 2002; Ferron et al., 2005; Massling et al., 2005; Swietlicki et al., 2008, and references therein; Laborde et al., 2013; Lance et al., 2013; Ye et al., 2013; Cai et al., 2017). Our data are slightly above the typical $\mathrm{HGF}_{\mathrm{NH}}$ and slightly below the typical $\mathrm{HGF}_{\mathrm{LH}}$ values (for a summary list see Swietlicki et al., 2008, Table 3). Laborde et al. (2013) further observed that the fresh traffic emissions have virtually hydrophobic behaviour, which is also close to our conclusion on the NH mode. The studies also reported the presence of a MH mode, which was not present in our data set. This mode is attributed in most cases either to the aged continental, mostly soot-free background aerosol particles (Liu et al., 2013) entering the urban air or to particles from efficient biomass burning (BB; Swietlicki et al., 2008). The missing $\mathrm{MH}$ mode in Budapest suggests that particles from local urban and rural regional sources seem more important inside the city than from continental background sources. This is coherent with the decreasing tendency in the annual mean UF particle number concentration from the city centre of Budapest $\left(8.4 \pm 5.3 \times 10^{3} \mathrm{~cm}^{-3}\right)$ through its near-city background $\left(3.1 \pm 2.8 \times 10^{3} \mathrm{~cm}^{-3}\right)$ to the more distant rural background $\left(3.8 \pm 3.6 \times 10^{3} \mathrm{~cm}^{-3}\right.$; Salma et al., 2014, $2016 \mathrm{~b}$ ), and with the estimated total concentrations for the continental background down to $500-800 \mathrm{~cm}^{-3}$ (Raes et al., 2000). The distance of Budapest from the sea (see Sect. 2) can possibly play a role. As far as the BB is concerned, it was recently estimated that the mean contribution and SD of $\mathrm{OC}$ from $\mathrm{BB}$ to the total carbon in central Budapest in winter was the largest single value of $34 \pm 8 \%$, with contributions from fossil fuel combustion and biogenic emissions of $25 \pm 6$ and $24 \pm 9 \%$, respectively (Salma et al., 2017). The particles emitted from high-temperature efficient BB are rich in alkali salts and contain depleted amounts of organic compounds; thus they are expected to be very hygroscopic (Mircea et al., 2005; Rissler et al., 2005). The absence of the $\mathrm{MH}$ mode in Budapest could indirectly and partially imply that BB in the area likely took place as low-temperature incomplete combustion of biofuels, which produces organic aerosol constituents with limited water uptake. This hypothesis, however, needs to be further studied.

\subsection{Diurnal variations}

Mean diurnal variation of the number fractions of the $\mathrm{NH}$ and LV modes (Fig. 3) showed relatively large change during the day and displayed a shape which corresponds to the
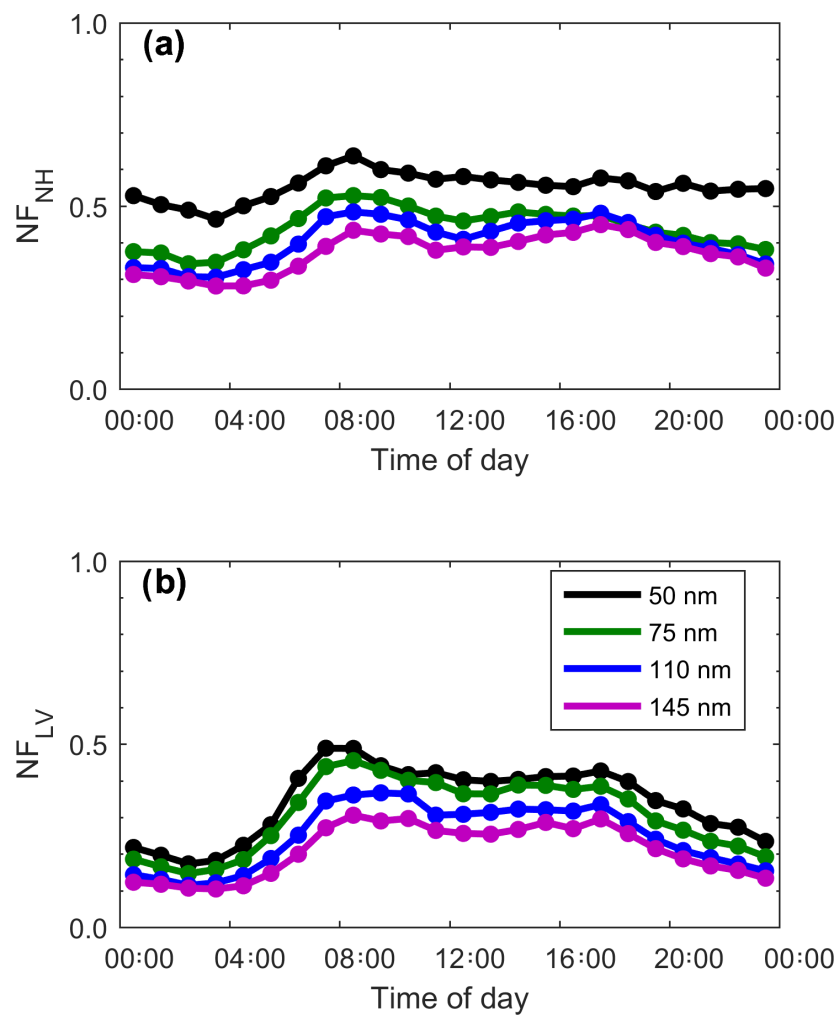

Figure 3. Mean diurnal variation of the number fraction of particles in the nearly hydrophobic mode $\left(\mathrm{NF}_{\mathrm{NH}} ; \mathbf{a}\right)$ and less volatile mode $\left(\mathrm{NF}_{\mathrm{LV}} ; \mathbf{b}\right)$ for different dry particle diameters. The panels have shared legends.

typical daily activity time pattern of inhabitants in cities, including particularly the road traffic in Budapest (Salma et al., 2011a). It consists of two peaks at approximately 08:00 and 18:00 LT, which coincide with the most intensive vehicle traffic (morning and afternoon rush hours). This diurnal pattern of the modes was also strongly correlated with $N$ (correlation coefficients of $R=0.907$ and 0.882 for the $\mathrm{NH}$ and LV modes, respectively), and it is known that the total particle number concentration is mainly influenced by traffic emissions (Salma et al., 2014). It was also found that the $\mathrm{NF}_{\mathrm{LV}}$ began to elevate already before the sunrise in winter and, hence, before boundary layer mixing or photochemistry could intensively take place. This all implies that the $\mathrm{NH}$ and LV particles are related to the direct emissions from road vehicles.

Diurnal variation in the hygroscopicity was more complex. The mean diurnal dependency of the $\kappa$ value for all data, and separately for the $\mathrm{NH}$ and $\mathrm{LH}$ modes $\left(\kappa_{\mathrm{NH}}\right.$ and $\kappa_{\mathrm{LH}}$, respectively), is shown in Fig. 4 . The diurnal pattern of the $\kappa_{\text {mean }}$ value for all data (Fig. 4a) showed the largest values during the early morning hours. This is different from those found in other studies in urban air. Lance et al. (2013) and Bialek et al. (2014) observed a larger mean $\kappa$ value than in the present work, and its diurnal variation was different. 

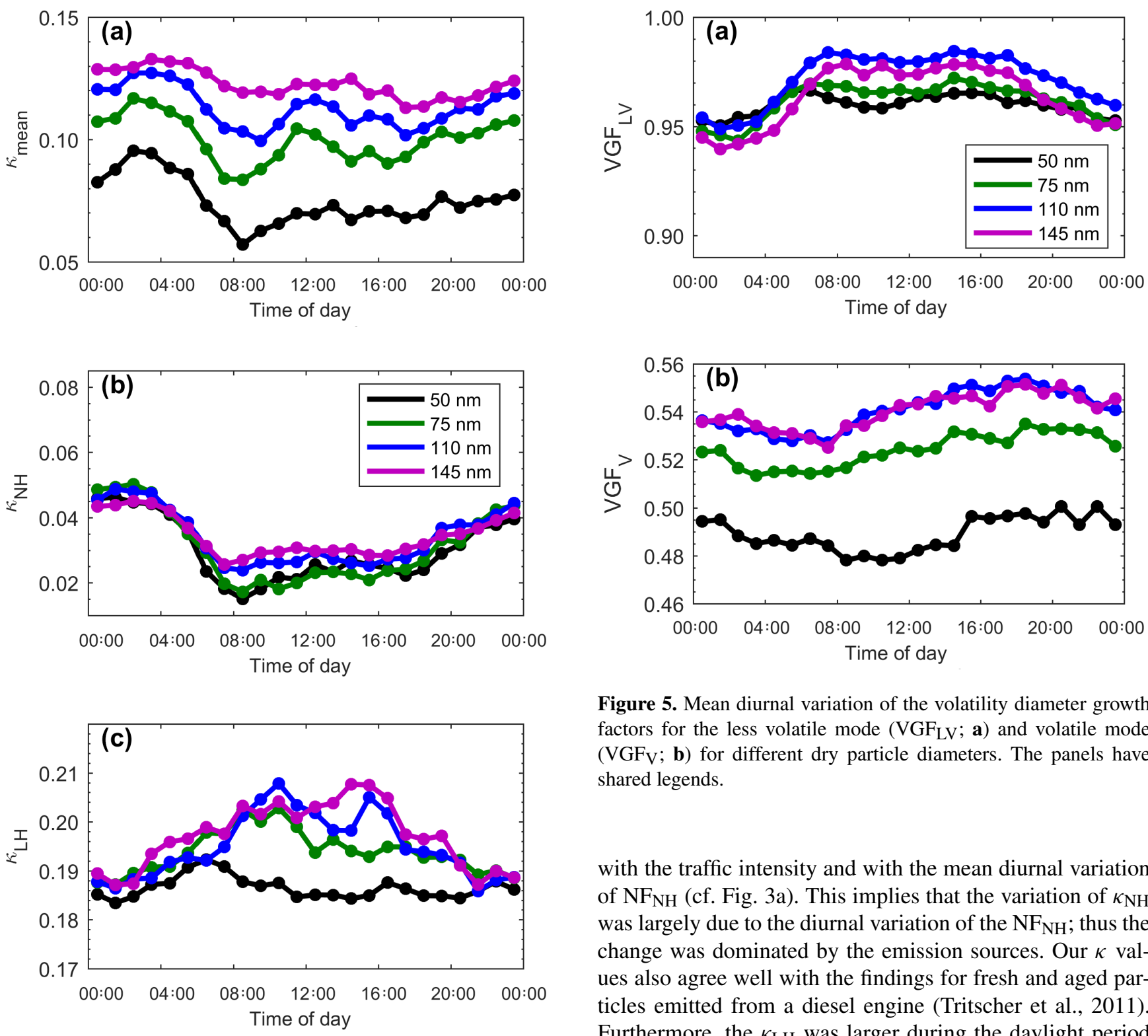

Figure 5. Mean diurnal variation of the volatility diameter growth factors for the less volatile mode $\left(\mathrm{VGF}_{\mathrm{LV}} ; \mathbf{a}\right)$ and volatile mode $\left(\mathrm{VGF}_{\mathrm{V}}\right.$; b) for different dry particle diameters. The panels have shared legends.

Figure 4. Mean diurnal variation of the hygroscopicity parameter $\kappa$ for all data $\left(\kappa_{\text {mean }} ; \mathbf{a}\right)$, separately for the nearly hydrophobic mode $\left(\kappa_{\mathrm{NH}} ; \mathbf{b}\right)$ and less hygroscopic mode $\left(\kappa_{\mathrm{LH}} ; \mathbf{c}\right)$ for different dry particle diameters. The panels have shared legends.

Their lowest hygroscopicity occurred in the early morning hours (around 05:00 LT), followed by a steady increase until the early afternoon, when it started to decrease towards the early morning minimum. The differences can be likely explained by the fact that the locations of the previous two studies cannot be strictly regarded as city centre, and a strong natural/regional aerosol component could be present. This is further supported by the fact that the diurnal cycles they found are similar to those obtained for a remote site at Hyytiälä, Finland (Ehn et al., 2007). The diurnal hygroscopicity curves for the NH mode (Fig. 4b) were obviously anti-correlated 

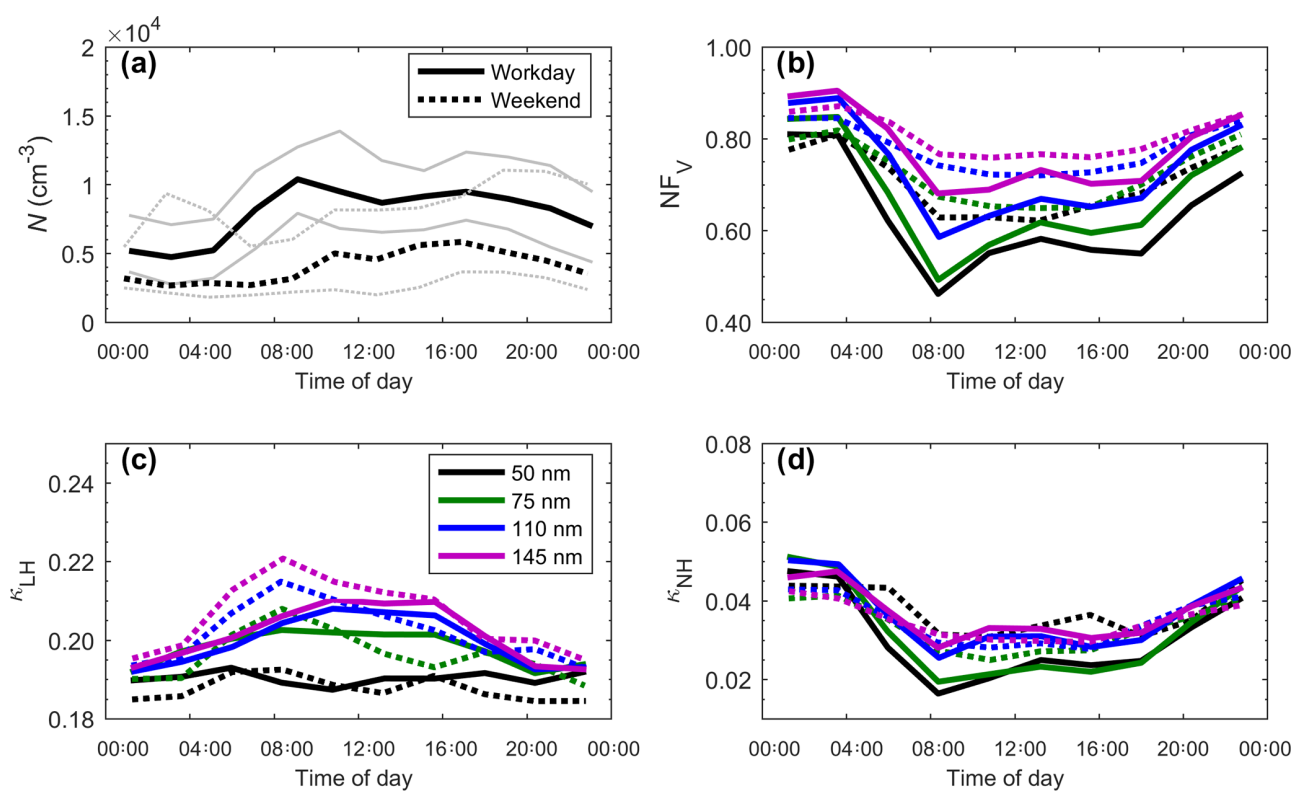

Figure 6. Diurnal variation of the median total particle number concentration $(N ; \mathbf{a})$, and the mean particle number fraction of volatile particles $\left(\mathrm{NF}_{\mathrm{V}} ; \mathbf{b}\right)$, the mean hygroscopicity parameter of the less hygroscopic mode $\left(\kappa_{\mathrm{LH}} ; \mathbf{c}\right)$ and nearly hydrophobic mode $\left(\kappa_{\mathrm{NH}}\right.$; d $)$ separately for workdays (solid lines) and weekends (dotted lines) for different dry particle diameters. The thin lines in grey in (a) represent the lower and upper quartiles of the corresponding concentration data. (b), (c) and (d) have shared legends.

that the changes in the $\kappa_{\text {mean }}$ are better explained by a changing number fraction of particles in each mode than by the size-dependent changes in chemical composition.

The $V_{G F}$ showed a clear daily activity time pattern (Fig. 5a). This indicates that the particles in the LV mode were mainly generated by vehicle road traffic. Particles with diameters of 50 and $70 \mathrm{~nm}$ seemed somewhat more volatile during the daylight time period than the 110 and $145 \mathrm{~nm}$ particles. The larger particles also had a larger magnitude in the VGF daily variation than the smaller particles. This means that the larger particles in the LV mode had more variation in their composition, and could consist of fresh non-volatile traffic emissions which collected or adsorbed condensing organics on their surface. For the $\mathrm{VGF}_{\mathrm{V}}$ (Fig. 5b), no obvious diurnal pattern was observed for any particle diameter. The associated particles showed more or less constant VGFs during the day. The smallest particles investigated (with a diameter of $50 \mathrm{~nm}$ ) were separated from the others and exhibited larger volatility $(\mathrm{VGF}<0.5)$ than for the other diameters, while particles with diameters of 110 and $145 \mathrm{~nm}$ showed almost identical volatile properties.

\subsection{Relationships between workdays and weekends}

The overall influence of vehicle emissions on the hygroscopicity and volatility of particles was studied by evaluating the data set separately for workdays and weekends. There is less vehicular road traffic during the weekends than on workdays (Salma et al., 2011a). Due to the limited residence time of particles with the selected diameters, their concentration lev- els on workdays and holidays also differ considerably because of their different source intensities. This facilitates the comparison of workdays and holidays. Diurnal variation of the total particle number concentration, of the fraction of particles in the volatile mode and of the hygroscopicity parameter of the $\mathrm{NH}$ and $\mathrm{LH}$ modes for workdays and weekends is shown in Fig. 6. It is seen in Fig. 6a that the $N$ increased monotonically and rapidly from 05:30 to 07:00 LT on workdays and reached its first maximum between 07:00 and 08:00 LT. The concentration remained at an elevated level over the whole daylight time period. A second broader maximum appeared at around 18:00LT, and the $N$ decreased monotonically after this peak till about 04:00 LT the next morning. On weekends, the morning growth was slower, the first maximum was shifted to approximately 11:00 LT and its amplitude was much smaller. The remaining part of the curve was similar in shape to that for workdays but reached considerably lower levels than on workdays. These are in good agreement with ordinary vehicular traffic flow in central Budapest (Salma et al., 2011a) except for the fact that the mean traffic flow from 00:00 to 05:00 LT is usually larger on weekends than on workdays. This latter difference can be likely explained by the changes in the composition of the vehicle fleet on workdays and weekends (fewer buses and heavyduty vehicles on weekends and particularly overnight). Influence of the road traffic was clearly manifested in the diurnal variation of the number fraction of particles in the volatile mode (Fig. 6b), which essentially varied inversely with the $N$ and traffic intensity. This probably indicated less variabil- 
ity in or constant shape of the $N_{\mathrm{V}}$ concentration during the day. The extent of the decrease for the morning and evening rush hours decreased monotonically with the particle diameter. The hygroscopicity parameters for the LH mode on workdays or on weekends (Fig. 6c) were similar to each other. They were basically comparable to each other in extent and were without very evident diurnal variation for both workdays and weekends, except for the particles with a diameter of $50 \mathrm{~nm}$, for which the $\kappa_{\mathrm{LH}}$ was the smallest and more or less constant. For the other diameters, the $\kappa_{\mathrm{LH}}$ values were somewhat larger, and they also showed larger values during the daylight time than at night for both workdays and weekends, though their shape was mostly featureless. For weekends, the $\kappa_{\mathrm{LH}}$ reached their largest value in the early morning hours and seemed to be somewhat larger than for the workdays. The diurnal variation curves for the hygroscopicity of the $\mathrm{NH}$ mode were similar to each other separately for workdays and for weekends (Fig. 6d). The curves showed an inverse shape with the $N$ and traffic intensity (cf. Fig. 6a). There was a larger decrease in the hygroscopicity parameter in the morning rush hours for workdays than for weekends, in particular for particles with diameters of 50 and $75 \mathrm{~nm}$.

\subsection{Conjugate hygroscopic and volatile properties}

Relationships between the hygroscopic and volatile properties were studied by relating their mean values to each other directly (Fig. 7a) and by deriving the mean VFR from the particles after the thermal treatment as a function of the mean HGF (Fig. 7b). The latter property represents a very expressive picture of the physical appearance of the coating and core of particles, and of their volume ratio. Both the VGF and VFR decreased monotonically with the hygroscopicity of particles. The relationships were size dependent, which may indicate that there were different abundances and/or different chemical species mainly of organic compounds in the particles with different dry diameters. A levelling-off tendency was observed for particles with diameters of 110 and $145 \mathrm{~nm}$ at larger HGF values, and they also started to behave in a similar manner to each other. Importantly, the VFR dependency for these two particle diameters seemed also to be limited from the bottom at approximately VFR $=25 \%$. This estimate is in good agreement with the conclusions obtained in an earlier study (Cheung et al., 2016) and seems to indicate an urban feature. This all jointly suggests that the volatile and hygroscopic properties varied in a coherent manner; that the hygroscopic compounds were usually volatile; and that the larger particles contained internally mixed non-volatile chemical species in a considerable volumetric ratio as a refractory residual, which could be core-like soot or organic polymers.

There were further important links between the modes of the hygroscopicity and volatility probability density functions. Figure 8 shows the mean diurnal variation of $\kappa$-PDF and VGF-PDF for various dry diameters. It is worth men-
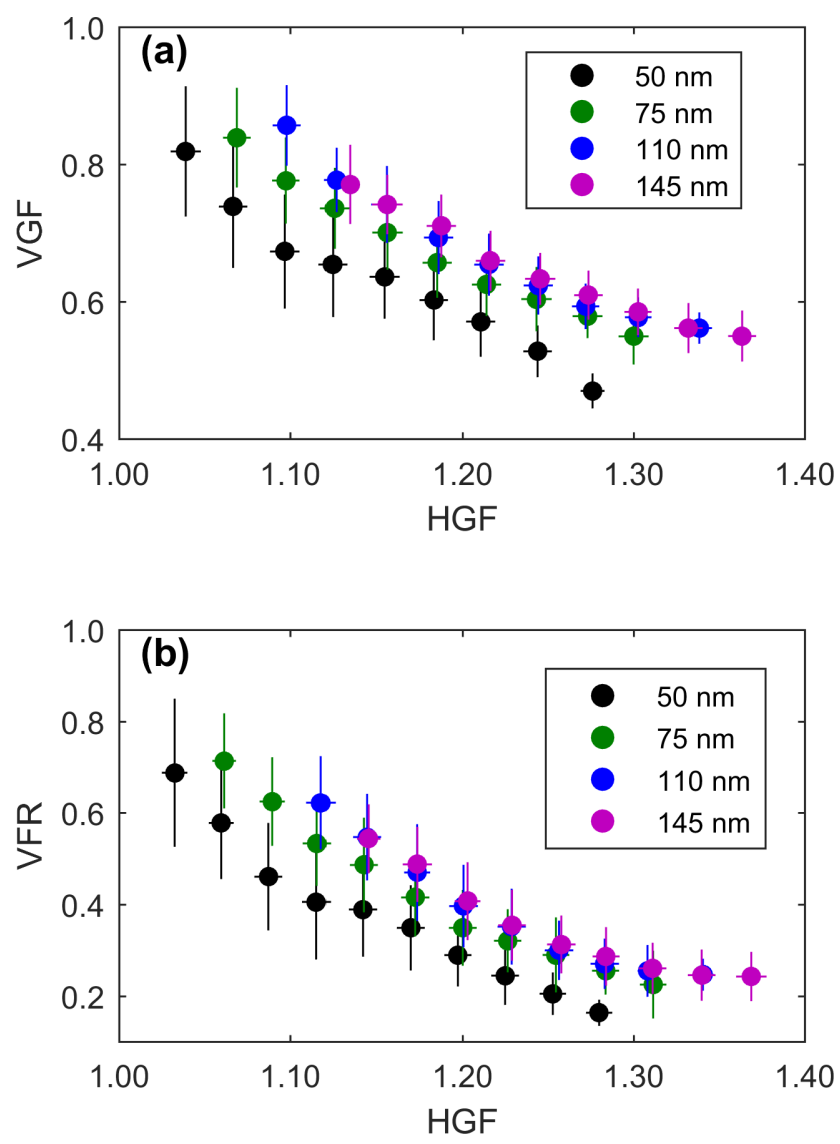

Figure 7. Relationship between the mean hygroscopic growth factors (HGFs) and the conjugate volatility growth factors (VGFs; a), and between the HGFs and the conjugate volume fraction remaining (VFR) after the thermal treatment (b) obtained at a mean relative humidity and at a mean temperature of $90 \%$ and $270{ }^{\circ} \mathrm{C}$, respectively, for different dry particle diameters. The error bars indicate $\pm 1 \mathrm{SD}$.

tioning that the colour coding depicts the normalized concentration fractions, not the absolute values. For instance, the decrease in the volatile mode during the daytime was caused by appearance of less volatile particles in large numbers. The $\mathrm{NH}$ mode consisted of a mixture of particles with a $\kappa<0.05$ and a $\kappa \approx 0.05$. During the daytime interval, large numbers of small, very low hygroscopicity particles appeared in the NH mode and began dominating the particle number concentrations for particles with diameters of 50 and $75 \mathrm{~nm}$. Their influence was lower but still apparent for larger particles as well. Road traffic is the most likely source for these particles based on their size range and the timing of their appearance. Furthermore, the corresponding occurrence of the LV mode (Fig. 8, lower panels) supports the conclusion that road traffic was a major source of these particles. The NH mode for the larger particles was likely associated with a mixture of aged particles from traffic sources and biomass burning emissions as they are present during the day (Salma et al., 2017) 


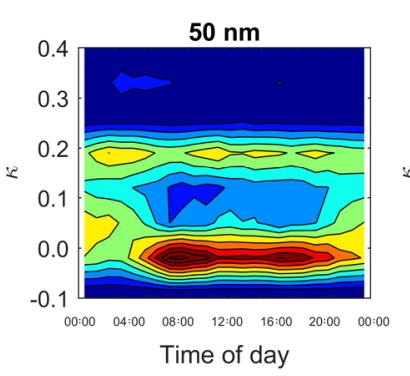

$50 \mathrm{~nm}$

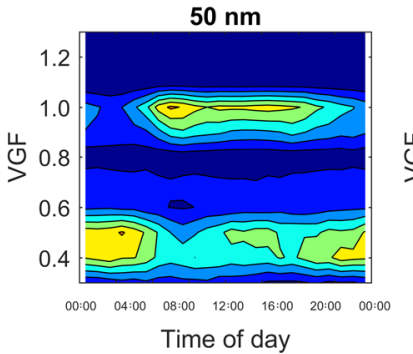

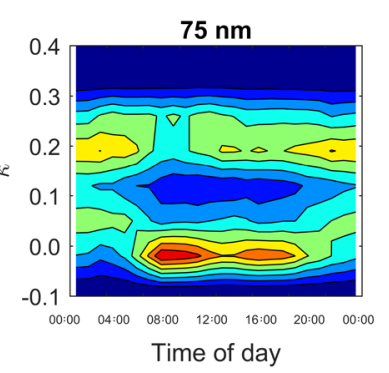

$75 \mathrm{~nm}$

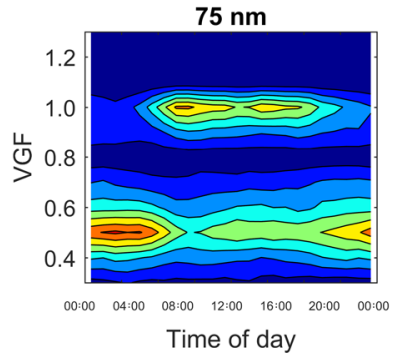

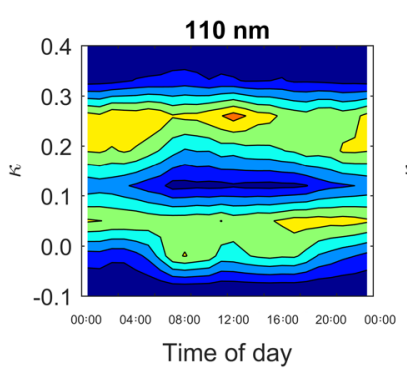

$110 \mathrm{~nm}$

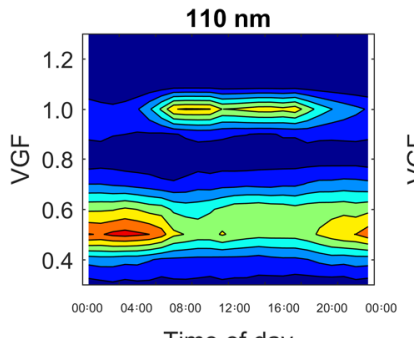

Time of day

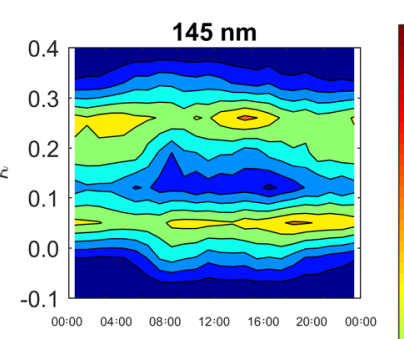

Time of day

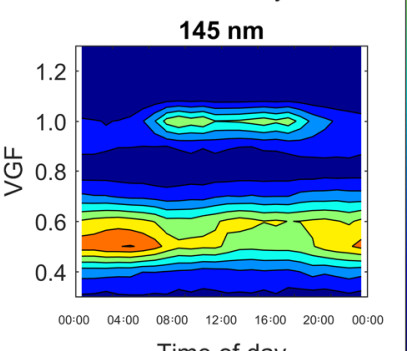

Time of day

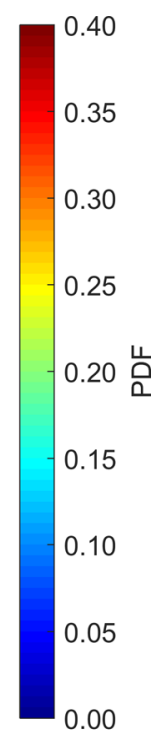

Figure 8. Mean diurnal variation of the hygroscopicity parameter $\kappa$ and volatility growth factor (VGF) probability distribution function (PDF) for particles with different dry diameters. The negative $\kappa$ values are an artefact of plotting the data.

and still show considerably low hygroscopicity. For the LH mode, the intermodal variation was less apparent. This mode showed a diurnal variation with a daytime maximum, which is similar to that observed for the overall hygroscopicity at rural sites (Ehn et al., 2007). The intermodal variation for VGFs can be explained by a constant background of volatile particles and by a varying contribution from less volatile particles from traffic emission. The observed decrease in VGFPDF during daytime was caused by an increase in the total number of non-volatile particles, likely originating from traffic. This diminished the number fraction of the volatile mode and, hence, caused the decrease in the PDF, while the actual number concentration of particles in the volatile mode remained relatively stable.

\section{Conclusions}

Hygroscopic GFs, volatility GFs and hygroscopicity parameters were quantified for ambient aerosol particles with dry diameters of (20), 50, 75, 110 and $145 \mathrm{~nm}$ in situ by using a VH-TDMA system in central Budapest during 2 months in winter. The measurements were supported by a DMPS system and meteorological sensors, which were operated in parallel. The urban aerosol showed distinct bimodality with respect to both hygroscopic and volatile properties, which indicated that the urban aerosol contains an external mixture of particles with a diverse chemical composition. Vehicular road traffic had significant influence on both the hygroscopic and volatile properties, and contributed substantially to the particles in the NH and LV modes. These two modes were associated with each other, and both followed the typical diurnal pattern of road traffic and its workday-weekend variation. The LH mode was most likely composed of moderately transformed aged combustion particles consisting of partly oxygenated organics, inorganic salts and soot, and typically exhibited a VGF of approximately 0.6. Both the HGFs and VGFs showed modest size-dependent behaviour, while the particles number fraction in the modes exhibited much stronger size dependency. Smaller particle diameters were associated with a larger number fraction of non-volatile and hydrophobic particles than the larger diameters. This can be explained by assuming that the larger particles grew by condensation of organic vapours, and it is also supported by the week dependency of the $\kappa$ values with respect to the dry particle size. The $50 \mathrm{~nm}$ particles, however, had a considerably lower $\kappa$ value and showed larger volatility during daytime in the LH mode with respect to the larger diameters. This suggests that these particles have different chemical composition than the larger particles. In general, the particles were mainly affected by local/urban emissions, and the aged particles were well separated from the freshly emitted ones.

The transformation process of soot particles from hydrophobic to hydrophilic in the real atmosphere is still not sufficiently understood and constrained. The present study emphasises the importance of the mixing state of particles for influencing their hygroscopic properties. The ambient conditions during the campaign were typical for wintertime $\mathrm{Bu}-$ dapest. Since there are strong seasonal variations in both the anthropogenic-natural and primary-secondary components, the hygroscopic and volatile properties are also expected to change over the course of a year. Therefore, further similar in situ measurements should be carried out in different seasons in the future together with online chemical characterisation of particles to better quantify and understand the properties, relevance and role of urban aerosol. 
The results and conclusion achieved in the present study cover a geographical region in central Europe, which is much less represented and documented by similar measurements. This can already indicate a general value of our contribution. In addition to that, our findings could in principle be compared to earlier studies performed specifically in urban environments in the word. Nevertheless, there are substantial differences among cities and their associated larger regions, which also means that a perspective comparative analysis should be detailed enough; it is expected to be extended and, more importantly, to deal with systematic methods of identifying and quantifying similarities and differences. The present work indicates the need for such an overview work in the future if the number of cities with available corresponding data further increases.

Data availability. The observational data used in this paper are available on request from Joonas Enroth.

Competing interests. The authors declare that they have no conflict of interest.

Acknowledgements. Financial support by the National Research, Development and Innovation Office, Hungary (contracts K116788 and PD124283); by the European Regional Development Fund and the Hungarian Government (GINOP-2.3.2-15-2016-00028); by the European Commission H2020 research and innovation programme via ACTRIS-2 (grant agreement 654109); by the European Research Council (ERC-advanced grant, ATM-GTP); and by the Academy of Finland, Center of Excellence (project 307331) and Academy Professor Project (Markku Kulmala) is gratefully acknowledged.

Edited by: Chak K. Chan

Reviewed by: three anonymous referees

\section{References}

Baltensperger, U., Streit, N., Weingartner, E., Nyeki, S., Prévôt, A. S. H., Van Dingenen, R., Virkkula, A., Putaud, J.-P., Even, A., ten Brink, H., Blatter, A., Neftel, A., and Gäggeler, H. W.: Urban and rural aerosol characterization of summer smog events during the PIPAPO field campaign in Milan, Italy, J. Geophys. Res., 107, 8193, https://doi.org/10.1029/2001JD001292, 2002.

Bialek, J., Dall Osto, M., Vaattovaara, P., Decesari, S., Ovadnevaite, J., Laaksonen, A., and O'Dowd, C.: Hygroscopic and chemical characterisation of Po Valley aerosol, Atmos. Chem. Phys., 14, 1557-1570, https://doi.org/10.5194/acp-14-1557-2014, 2014.

Boucher, O., Randall, D., Artaxo, P., Bretherton, C., Feingold, G., Forster, P., Kerminen, V.-M., Kondo, Y., Liao, H., Lohmann, U., Rasch, P., Satheesh, S. K., Sherwood, S., Stevens, B., and Zhang, X. Y.: Clouds and Aerosols, in: Climate Change 2013: The Physical Science Basis, in: Contribution of Working Group I to the
Fifth Assessment Report of the Intergovernmental Panel on Climate Change, edited by: Stocker, T. F., Qin, D., Plattner, G.-K., Tignor, M., Allen, S. K., Boschung, J., Nauels, A., Xia, Y., Bex, V., and Midgley, P. M., Cambridge University Press, Cambridge, UK, 571-658, 2013.

Brimblecombe, P.: Urban Pollution and Changes to Materials and Building Surfaces, Imperial College Press, London, 2016.

Cai, M. F., Tan, H. B., Chan, C. K., Mochida, M., Hatakeyama, S., Kondo, Y., Schurman, M. I., Xu, H. B., Li, F., Shimada, K., Liu, L., Deng, Y. G., Yai, H., Matsuki, A., Qin, Y. M., and Zhao, J.: Comparison of aerosol hygroscopicity, volatility, and chemical composition between a suburban site in the Pearl River Delta Region and a marine site in Okinawa, Aerosol Air Qual. Res., 17, 3194-3208, 2017.

Chan, M. N. and Chan, C. K.: Mass transfer effects in hygroscopic measurements of aerosol particles, Atmos. Chem. Phys. 5, 2703-2712, https://doi.org/10.5194/acp-5-2703-2005, 2005.

Cheng, Y. F., Eichler, H., Wiedensohler, A., Heintzenberg, J., Zhang, Y. H., Hu, M., Herrmann, H., Zeng, L. M., Liu, S., Gnauk, T., Brüggemann, E., and He, L. Y.: Mixing state of elemental carbon and non-light-absorbing aerosol components derived from in situ particle optical properties at Xinken in Pearl River Delta of China, J. Geophys. Res., 111, D20204, https://doi.org/10.1029/2005JD006929, 2006.

Cheung, H. H. Y., Tan, H., Xu, H., Li, F., Wu, C., Yu, J. Z., and Chan, C. K.: Measurements of non-volatile aerosols with a VTDMA and their correlations with carbonaceous aerosols in Guangzhou, China, Atmos. Chem. Phys., 16, 8431-8446, https://doi.org/10.5194/acp-16-8431-2016, 2016.

Cocker, D., Whitlock, N., Flagan, R., and Seinfeld, J. H.: Hygroscopic properties of Pasadena, California aerosol, Aerosol Sci. Tech., 35, 637-647, 2001.

Davidson, C. I., Phalen, R. F., and Solomon, P. A.: Airborne Particulate Matter and Human Health: A Review, Aerosol Sci. Tech., 39, 737-749, 2005.

Duplissy, J., Gysel, M., Sjogren, S., Meyer, N., Good, N., Kammermann, L., Michaud, V., Weigel, R., Martins dos Santos, S., Gruening, C., Villani, P., Laj, P., Sellegri, K., Metzger, A., McFiggans, G. B., Wehrle, G., Richter, R., Dommen, J., Ristovski, Z., Baltensperger, U., and Weingartner, E.: Intercomparison study of six HTDMAs: results and recommendations, Atmos. Meas. Tech., 2, 363-378, https://doi.org/10.5194/amt-2363-2009, 2009.

Duplissy, J., DeCarlo, P. F., Dommen, J., Alfarra, M. R., Metzger, A., Barmpadimos, I., Prevot, A. S. H., Weingartner, E., Tritscher, T., Gysel, M., Aiken, A. C., Jimenez, J. L., Canagaratna, M. R., Worsnop, D. R., Collins, D. R., Tomlinson, J., and Baltensperger, U.: Relating hygroscopicity and composition of organic aerosol particulate matter, Atmos. Chem. Phys., 11, 11551165, https://doi.org/10.5194/acp-11-1155-2011, 2011.

Ehn, M., Petäjä, T., Aufmhoff, H., Aalto, P., Hämeri, K., Arnold, F., Laaksonen, A., and Kulmala, M.: Hygroscopic properties of ultrafine aerosol particles in the boreal forest: diurnal variation, solubility and the influence of sulfuric acid, Atmos. Chem. Phys., 7, 211-222, https://doi.org/10.5194/acp-7-211-2007, 2007.

Facchini, M. C., Mircea, M., Fuzzi, S., and Charlson, R. J.: Cloud albedo enhancement by surface-active organic solutes in growing droplets, Nature, 401, 257-259, 1999. 
Ferron, G. A., Karg, E., Busch, B., and Heyder, J.: Ambient particles at an urban, semi-urban and rural site in Central Europe: Hygroscopic properties, Atmos. Environ., 39, 343-352, 2005.

Gysel, M., McFiggans, G. B., and Coe, H.: Inversion of tandem differential mobility analyser (TDMA) measurements, J. Aerosol Sci., 40, 134-151, 2009.

Hakala, J., Mikkilä, J., Hong, J., Ehn, M., and Petäjä, T.: VHTDMA: A description and verification of an instrument to measure aerosol particle hygroscopicity and volatility, Aerosol Sci. Tech., 51, 97-107, 2017.

Häkkinen, S. A. K., Äijälä, M., Lehtipalo, K., Junninen, H., Backman, J., Virkkula, A., Nieminen, T., Vestenius, M., Hakola, H., Ehn, M., Worsnop, D. R., Kulmala, M., Petäjä, T., and Riipinen, I.: Long-term volatility measurements of submicron atmospheric aerosol in Hyytiälä, Finland, Atmos. Chem. Phys., 12, 1077110786, https://doi.org/10.5194/acp-12-10771-2012, 2012.

Henning, S., Ziese, M., Kiselev, A., Saathoff, H., Möhler, O., Mentel, T. F., Buchholz, A., Spindler, C., Michaud, V., Monier, M., Sellegri, K., and Stratmann, F.: Hygroscopic growth and droplet activation of soot particles: uncoated, succinic or sulfuric acid coated, Atmos. Chem. Phys., 12, 4525-4537, https://doi.org/10.5194/acp-12-4525-2012, 2012.

Hong, J., Häkkinen, S. A. K., Paramonov, M., Äijälä, M., Hakala, J., Nieminen, T., Mikkilä, J., Prisle, N. L., Kulmala, M., Riipinen, I., Bilde, M., Kerminen, V.-M., and Petäjä, T.: Hygroscopicity, $\mathrm{CCN}$ and volatility properties of submicron atmospheric aerosol in a boreal forest environment during the summer of 2010, Atmos. Chem. Phys., 14, 4733-4748, https://doi.org/10.5194/acp14-4733-2014, 2014.

Jurányi, Z., Tritscher, T., Gysel, M., Laborde, M., Gomes, L., Roberts, G., Baltensperger, U., and Weingartner, E.: Hygroscopic mixing state of urban aerosol derived from sizeresolved cloud condensation nuclei measurements during the MEGAPOLI campaign in Paris, Atmos. Chem. Phys., 13, 64316446, https://doi.org/10.5194/acp-13-6431-2013, 2013.

Kamilli, K. A., Poulain, L., Held, A., Nowak, A., Birmili, W., and Wiedensohler, A.: Hygroscopic properties of the Paris urban aerosol in relation to its chemical composition, Atmos. Chem. Phys., 14, 737-749, https://doi.org/10.5194/acp-14-7372014, 2014.

Kerminen, V.-M. and Wexler, A. S.: Growth laws of atmospheric aerosol particles: an examination of the bimodality of the accumulation mode, Atmos. Environ., 22, 3263-3275, 1995.

Kerminen, V.-M., Paramonov, M., Anttila, T., Riipinen, I., Fountoukis, C., Korhonen, H., Asmi, E., Laakso, L., Lihavainen, H., Swietlicki, E., Svenningsson, B., Asmi, A., Pandis, S. N., Kulmala, M., and Petäjä, T.: Cloud condensation nuclei production associated with atmospheric nucleation: a synthesis based on existing literature and new results, Atmos. Chem. Phys., 12, 1203712059, https://doi.org/10.5194/acp-12-12037-2012, 2012.

Kitamori, Y., Mochida, M., and Kawamura, K.: Assessment of the aerosol water content in urban atmospheric particles by the hygroscopic growth measurements in Sapporo, Japan, Atmos. Environ., 43, 3416-3423, 2009.

Kulmala, M., Petäjä, T., Nieminen, T., Sipilä, M., Manninen, H. E., Lehtipalo, K., Dal Maso, M., Aalto, P. P., Junninen, H., Paasonen, P., Riipinen, I., Lehtinen, K. E. J., Laaksonen, A., and Kerminen, V.-M.: Measurement of the nucleation of atmospheric aerosol particles, Nat. Protocols, 7, 1651-1667, 2012.
Kuwata, M. and Kondo, Y.: Dependence of size-resolved CCN spectra on the mixing state of nonvolatile cores observed in Tokyo, J. Geophys. Res., 113, D19202, https://doi.org/10.1029/2007JD009761, 2008.

Laborde, M., Crippa, M., Tritscher, T., Jurányi, Z., Decarlo, P. F., Temime-Roussel, B., Marchand, N., Eckhardt, S., Stohl, A., Baltensperger, U., Prévôt, A. S. H., Weingartner, E., and Gysel, M.: Black carbon physical properties and mixing state in the European megacity Paris, Atmos. Chem. Phys., 13, 5831-5856, https://doi.org/10.5194/acp-13-5831-2013, 2013.

Lance, S., Raatikainen, T., Onasch, T. B., Worsnop, D. R., Yu, X.Y., Alexander, M. L., Stolzenburg, M. R., McMurry, P. H., Smith, J. N., and Nenes, A.: Aerosol mixing state, hygroscopic growth and cloud activation efficiency during MIRAGE 2006, Atmos. Chem. Phys., 13, 5049-5062, https://doi.org/10.5194/acp-135049-2013, 2013.

Lelieveld, J., Evans, J. S., Fnais, M., Giannadaki, D., and Pozzer, A.: The contribution of outdoor air pollution sources to premature mortality on a global scale, Nature, 525, 367-71, 2015.

Liu, D., Allan, J., Whitehead, J., Young, D., Flynn, M., Coe, H., McFiggans, G., Fleming, Z. L., and Bandy, B.: Ambient black carbon particle hygroscopic properties controlled by mixing state and composition, Atmos. Chem. Phys., 13, 2015-2029, https://doi.org/10.5194/acp-13-2015-2013, 2013.

Liu, P. F., Zhao, C. S., Göbel, T., Hallbauer, E., Nowak, A., Ran, L., Xu, W. Y., Deng, Z. Z., Ma, N., Mildenberger, K., Henning, S., Stratmann, F., and Wiedensohler, A.: Hygroscopic properties of aerosol particles at high relative humidity and their diurnal variations in the North China Plain, Atmos. Chem. Phys., 11, 3479-3494, https://doi.org/10.5194/acp-11-3479-2011, 2011.

Martin, M., Tritscher, T., Jurányi, Z., Heringa, M. F., Sierau, B., Weingartner, E., Chirico, R., Gysel, M., Prévôt, A. S. H., Baltensperger, U., and Lohmann, U.: Hygroscopic properties of fresh and aged wood burning particles, J. Aerosol Sci., 56, 1529, 2012.

Massling, A., Stock, M., and Wiedensohler, A.: Diurnal, weekly, and seasonal variation of hygroscopic properties of submicrometer urban aerosol particles, Atmos. Environ., 39, 3911-3922, 2005.

Massling, A., Niedermeier, N., Hennig, T., Fors, E. O., Swietlicki, E., Ehn, M., Hämeri, K., Villani, P., Laj, P., Good, N., McFiggans, G., and Wiedensohler, A.: Results and recommendations from an intercomparison of six hygroscopicity-TDMA systems, Atmos. Meas. Tech., 4, 485-497, https://doi.org/10.5194/amt-4485-2011, 2011.

Massoli, P., Lambe, A. T., Ahern, A. T., Williams, L. R., Ehn, M., Mikkilä, J., Canagaratna, M. R., Brune, W. H., Onasch, T. B., Jayne, J. T., Petäjä, T., Kulmala, M., Laaksonen, A., Kolb, C. E., Davidovits, P., and Worsnop, D. R.: Relationship between aerosol oxidation level and hygroscopic properties of laboratory generated secondary organic aerosol (SOA) particles, Geophys Res. Lett., 37, L24801, https://doi.org/10.1029/2010GL045258, 2010.

McFiggans, G., Artaxo, P., Baltensperger, U., Coe, H., Facchini, M. C., Feingold, G., Fuzzi, S., Gysel, M., Laaksonen, A., Lohmann, U., Mentel, T. F., Murphy, D. M., O’Dowd, C. D., Snider, J. R., and Weingartner, E.: The effect of physical and chemical aerosol properties on warm cloud droplet activation, Atmos. 
Chem. Phys., 6, 2593-2649, https://doi.org/10.5194/acp-6-25932006, 2006.

McMurry, P. and Stolzenburg, M.: On the sensitivity of particle size to relative humidity for Los Angeles aerosols, Atmos. Environ., 23, 497-507, 1989.

Meng, Z. and Seinfeld, J. H.: On the source of the submicrometer droplet mode of urban and regional aerosols, Aerosol Sci. Tech., 20, 253-265, 1994.

Mercado, L., Bellouin, N., Sitch, S., Boucher, O., Huntingford, C., Wild, M., and Cox, P. M.: Impact of changes in diffuse radiation on the global land carbon sink, Nature, 458, 1014-1017, 2009.

Mircea, M., Facchini, M. C., Decesari, S., Cavalli, F., Emblico, L., Fuzzi, S., Vestin, A., Rissler, J., Swietlicki, E., Frank, G., Andreae, M. O., Maenhaut, W., Rudich, Y., and Artaxo, P.: Importance of the organic aerosol fraction for modeling aerosol hygroscopic growth and activation: a case study in the Amazon Basin, Atmos. Chem. Phys., 5, 3111-3126, https://doi.org/10.5194/acp5-3111-2005, 2005.

Németh, Z., Pósfai, M., Nyirő-Kósa, I., Aalto, P., Kulmala, M., and Salma, I.: Images and properties of individual nucleated particles, Atmos. Environ., 123, 166-170, 2015.

Park, K., Kim, J-S., and Park, S. H.: Measurements of hygroscopicity and volatility of atmospheric ultrafine particles during ultrafine particle formation events at urban, industrial, and coastal sites, Environ. Sci. Technol., 43, 6710-6716, 2009.

Petters, M. D. and Kreidenweis, S. M.: A single parameter representation of hygroscopic growth and cloud condensation nucleus activity, Atmos. Chem. Phys., 7, 1961-1971, https://doi.org/10.5194/acp-7-1961-2007, 2007.

Pringle, K. J., Tost, H., Pozzer, A., Pöschl, U., and Lelieveld, J.: Global distribution of the effective aerosol hygroscopicity parameter for $\mathrm{CCN}$ activation, Atmos. Chem. Phys., 10, 52415255, https://doi.org/10.5194/acp-10-5241-2010, 2010.

Raes, F., Van Dingenen, R., Vignati, E., Wilson, J., Putaud, J. P., Seinfeld, J. H., and Adams, P.: Formation and cycling of aerosol in the global troposphere, Atmos. Environ., 34, 4215-4240, 2000.

Rissler, J., Pagels, J., Swietlicki, E., Wierzbicka, W., Strand, M., Lillieblad, L., Sanati, M., and Bohgard, M.: Hygroscopic behavior of aerosol particles emitted from biomass fired grate boilers, Aerosol Sci. Tech., 39, 919-930, 2005.

Rissler, J., Svenningsson, B., Fors, E. O., Bilde, M., and Swietlicki, E.: An evaluation and comparison of cloud condensation nucleus activity models: Predicting particle critical saturation from growth at subsaturation, J. Geophys. Res., 115, D22208, https://doi.org/10.1029/2010jd014391, 2010.

Salma, I., Ocskay, R., Varga, I., and Maenhaut, W.: Surface tension of atmospheric humic-like substances in connection with relaxation, dilution, and solution pH, J. Geophys. Res., 111, D23205, https://doi.org/10.1029/2005JD007015, 2006.

Salma, I., Borsós, T., Aalto, P., and Kulmala, M.: Time-resolved number concentrations and size distribution of aerosol particles in an urban road tunnel, Boreal Environ. Res., 16, 262-272, 2011a.

Salma, I., Borsós, T., Weidinger, T., Aalto, P., Hussein, T., Dal Maso, M., and Kulmala, M.: Production, growth and properties of ultrafine atmospheric aerosol particles in an urban environment, Atmos. Chem. Phys., 11, 1339-1353, https://doi.org/10.5194/acp-11-1339-2011, 2011b.
Salma, I., Borsós, T., Németh, Z., Weidinger, T., Aalto, T., and Kulmala, M.: Comparative study of ultrafine atmospheric aerosol within a city, Atmos. Environ., 92, 154-161, 2014.

Salma, I., Németh, Z., Weidinger, T., Kovács, B., and Kristóf, G.: Measurement, growth types and shrinkage of newly formed aerosol particles at an urban research platform, Atmos. Chem. Phys., 16, 7837-7851, https://doi.org/10.5194/acp16-7837-2016, $2016 \mathrm{a}$.

Salma, I., Németh, Z., Kerminen, V.-M., Aalto, P., Nieminen, T., Weidinger, T., Molnár, Á., Imre, K., and Kulmala, M.: Regional effect on urban atmospheric nucleation, Atmos. Chem. Phys., 16, 8715-8728, https://doi.org/10.5194/acp-16-8715-2016, $2016 \mathrm{~b}$.

Salma, I., Németh, Z., Weidinger, T., Maenhaut, W., Claeys, M., Molnár, M., Major, I., Ajtai, T., Utry, N., and Bozóki, Z.: Source apportionment of carbonaceous chemical species to fossil fuel combustion, biomass burning and biogenic emissions by a coupled radiocarbon-levoglucosan marker method, Atmos. Chem. Phys., 17, 13767-13781, https://doi.org/10.5194/acp-17-137672017, 2017.

Swietlicki, E., Hansson, H. C., Hämeri, K., Svenningsson, B., Massling, A., McFiggans, G., McMurry, P. H., Petäjä, T., Tunved, P., Gysel, M., Topping, D., Weingartner, E., Baltensperger, U., Rissler, J., Wiedensohler, A., and Kulmala, M.: Hygroscopic properties of submicrometer atmospheric aerosol particles measured with H-TDMA instruments in various environments - a review, Tellus B, 60, 432-469, 2008.

Tiitta, P., Miettinen, P., Vaattovaara, P., Joutsensaari, J., Petäjä, T., Virtanen, A., Raatikainen, T., Aalto, P., Portin, H., Romakkaniemi, S., Kokkola, H., Lehtinen, K. E. J., Kulmala, M., and Laaksonen, A.: Roadside aerosol study using hygroscopic, organic and volatility TDMAs: Characterization and mixing state, Atmos. Environ., 44, 976-986, 2010.

Tritscher, T., Jurányi, Z., Martin, M., Chirico, R., Gysel, M., Heringa, M. F., DeCarlo, P. F., Sierau, B., Prévôt, A. S. H., Weingartner, E., and Baltensperger, U.: Changes of hygroscopicity and morphology during ageing of diesel soot, Environ. Res. Let., 6, 034026, https://doi.org/10.1088/1748-9326/6/3/034026, 2011.

Ye, X., Tang, C., Yin, Z., Chen, J., Ma, Z., Kong, L., Yang, X., Gao, W., and Geng, F.: Hygroscopic growth of urban aerosol particles during the 2009 Mirage-Shanghai Campaign, Atmos. Environ., 64, 263-269, 2013.

Wehner, B., Berghof, M., Cheng, Y. F., Achtert, P., Birmili, W., Nowak, A., Wiedensohler, A., Garland, R. M., Pöschl, U., Hu, M., and Zhu, T.: Mixing state of nonvolatile aerosol particle fractions and comparison with light absorption in the polluted Beijing region, J. Geophys. Res.-Atmos., 114, D00G17, https://doi.org/10.1029/2008JD010923, 2009.

Weingartner, E., Baltensperger, U., and Burtscher, H.: Growth and structural change of combustion aerosols at high relative humidity, Environ. Sci. Technol., 29, 2982-2986, 1995.

Weingartner, E., Burtscher, H., and Baltensperger, U.: Hygroscopic properties of carbon and diesel soot particles, Atmos. Environ., 31, 2311-2327, 1997.

Wiedensohler, A., Birmili, W., Nowak, A., Sonntag, A., Weinhold, K., Merkel, M., Wehner, B., Tuch, T., Pfeifer, S., Fiebig, M., Fjäraa, A. M., Asmi, E., Sellegri, K., Depuy, R., Venzac, H., Villani, P., Laj, P., Aalto, P., Ogren, J. A., Swietlicki, E., Williams, P., Roldin, P., Quincey, P., Hüglin, C., Fierz-Schmidhauser, R., Gysel, M., Weingartner, E., Riccobono, F., Santos, S., Grün- 
ing, C., Faloon, K., Beddows, D., Harrison, R., Monahan, C., Jennings, S. G., O’Dowd, C. D., Marinoni, A., Horn, H.-G., Keck, L., Jiang, J., Scheckman, J., McMurry, P. H., Deng, Z., Zhao, C. S., Moerman, M., Henzing, B., de Leeuw, G., Löschau, G., and Bastian, S.: Mobility particle size spectrometers: harmonization of technical standards and data structure to facilitate high quality long-term observations of atmospheric particle number size distributions, Atmos. Meas. Tech., 5, 657-685, https://doi.org/10.5194/amt-5-657-2012, 2012.
Wu, Z. J., Zheng, J., Shang, D. J., Du, Z. F., Wu, Y. S., Zeng, L. M., Wiedensohler, A., and Hu, M.: Particle hygroscopicity and its link to chemical composition in the urban atmosphere of Beijing, China, during summertime, Atmos. Chem. Phys., 16, 1123 1138, https://doi.org/10.5194/acp-16-1123-2016, 2016. 